This PDF is a selection from a published volume from the National Bureau of Economic Research

Volume Title: Governance, Regulation, and Privatization in the Asia-Pacific Region, NBER East Asia Seminar on Economics, Volume 12

Volume Author/Editor: Takatoshi Ito and Anne O. Krueger, editors

Volume Publisher: University of Chicago Press

Volume ISBN: 0-226-38679-1

Volume URL: http://www.nber.org/books/ito_04-1

Conference Date: June 28-30, 2001

Publication Date: January 2004

Title: Using Markets to Help Solve Public Problems

Author: John McMillan

URL: http://www.nber.org/chapters/c10184 


\title{
Using Markets to Help Solve Public Problems
}

\author{
John McMillan
}

Governments around the world have begun using markets as means to policy ends. Pollution control has been assigned to a market in emissions allowances. The right to use the electromagnetic spectrum for telecommunications has been auctioned off. In electricity supply, markets have replaced allocation by state agencies or regulated monopolies. In fishery management, tradable quotas have started to be used instead of direct regulation. ${ }^{1}$

Using markets to allocate public resources represents a middle ground between privatization and government control. It is not privatization because the government retains substantial control rights. It is not government control of the traditional kind because part of the decision-making over how the resources are employed takes place in markets rather than in the bureaucracy.

Controversy has dogged the adoption of markets by governments. Emissions trading is immoral, say some environmentalists, for it legitimates polluting. Critics of the spectrum auctions, like the technology guru Nicholas Negroponte (quoted in Financial Times, 8 June 2000, p. 5), say they amount to "an economically unsustainable tax" on the telecommunications industry, bringing high prices for consumers and stifling innovation. The high electricity prices in California following deregulation prompted

John McMillan is the Jonathan B. Lovelace Professor of Economics at the Graduate School of Business, Stanford University.

I thank Kyoji Fukau, Takatoshi Ito, Anne Krueger, Tsuruhiko Nambu, Tetsushi Sonobe, Dale Squires, and an anonymous referee for comments, and the Stanford Graduate School of Business for support.

1. Another such use of markets is in restructuring publicly owned railroads (see chap. 11 in this volume). Yet another is the proposal by the U.S. Shadow Financial Regulatory Committee (2000) that bank regulators create a new high-risk bond, the price of which would provide input into the regulators' decisions. 
calls to reregulate the industry. With the advent of tradable fishery quotas, says Greenpeace, "corporate interests are about to gobble up the rights to species of fish and turn them into private property. With privatization we lose our rights to have a say about how the oceans - something we all share - are being treated" (www.greenpeaceusa.org/features/itq.htm).

The case for using markets is a pragmatic one: They are justified only if they work better than the feasible alternatives. Do they? In what follows I ask what can be learned from these experiences in the use of markets as policy tools.

Governments can successfully use markets. Information is the key (as is elaborated in my recent book, McMillan 2002). The market processwhere it works well - generates information on which of the firms are able to put scarce resources to the best use and on what the highest value use is. This information is unlikely to be revealed via a political or administrative procedure. Well-functioning markets remove the need, in other words, for the government to pick winners.

The public sector's ability to use markets, however, is constrained. The very reasons that certain activities have historically been placed in the public sector - natural monopoly, externalities, common property - make implementing markets for them difficult. "Leave it to the market" is usually bad advice.

There are two senses in which markets are a limited tool (as is also explained in McMillan 2002). First, a market does not automatically work as it is supposed to. The design of the market matters. With an ordinary private-sector market, the rules and procedures that govern it have evolved over years of trial and error. A public-sector market, by contrast, is judged by how well it works from its inception. Its rules and procedures, therefore, must be exhaustively thought through in advance. For a market to deliver on its public-policy promise, the government must design it skillfully.

Second, a market can provide only part of the solution to a public problem. With spectrum rights, pollution rights, electricity, and fisheries, the market does its job only within a framework of continued government action. Where there are elements of common property, externality, or natural monopoly, regulation continues to be needed even after a market has been introduced. The role of the market is to help the regulators do their job more effectively.

\subsection{Spectrum Licenses}

Auctions have been used by numerous governments to allocate licenses to use the electromagnetic spectrum for telecommunications, starting in New Zealand in 1990 and then the United States in 1994 and followed by countries such as Australia, Mexico, Canada, the United Kingdom, Germany, Hong Kong, and Singapore. The Financial Times (2 November 2000) called the spectrum auctions "the world's largest concerted transfer 
of money from the corporate sector to state coffers." As of 2001 the U.S. auctions had fetched a total of $\$ 42$ billion. In 2000, an auction of spectrum licenses in the United Kingdom yielded \$34 billion, and one in Germany went to $\$ 46$ billion. $^{2}$

Before auctioning, spectrum licenses had been given away for free. Who received the right to use the spectrum was decided by administrative hearings, or, in the case of some U.S. cellular telephone licenses, by lottery. Spectrum auctions, it is sometimes claimed, have the drawback of raising the prices that consumers ultimately pay for services. Janice Hughes, of Spectrum Strategy Consultants, said of Hong Kong, "An auction would push the price of a single license to at least US\$1 billion per operator and, there is no question about it, those costs would be passed on to consumers in the form of substantially higher prices" (South China Morning Post, 21 August 2000, p. 3).

To argue this, however, is to confuse fixed and variable costs. A firm that cares about its profits bases its price on its marginal cost: that is, the cost of supplying an additional customer with the service. The auction price is paid before any service is provided - it is a fixed cost - so it is not part of the marginal cost of supplying the service and does not affect the price charged to customers. There is a caveat to this fixed-cost argument. If capital-market frictions mean that the more the firm borrows, the higher the interest rate it must pay, then the extra debt added by the auction price could result in the firm's investing less and having a higher marginal cost. This caveat aside, the auction revenue is a pure transfer from the firm's profits to the government. The price to users would be almost the same whether the government sold the spectrum or gave it away.

Yet another complaint is that auctions favor large bidders with deep pockets, so new entrants find it hard to compete. Against this view is the fact that the 1990s, the period in which market forces came into the telecommunications industry, in fact saw far more entries than before. The alternative to auctions, administrative processes, are not notably open to outsiders. It may be easier for a new firm to raise money to bid in an auction than to become a player in the political process. Governments that use so-called beauty contests to assign spectrum often favor the incumbents. When South Korea awarded two mobile licenses by an administrative procedure in 2000, for example, it selected from several applicants the two that were already the most entrenched: SK Telecom, Korea's biggest mobile provider, and Korea Telecom, which is state run. Auctions are more transparent than most administrative procedures. (This is another aspect of the information-provision feature of auctions: they enable the public to see how the decision is made.) This transparency puts a brake on government favoritism.

Mexico provides evidence against the doomsayers. The auctioning of

2. On the European experience with spectrum auctions, see Klemperer (2002). 
spectrum licenses, from 1996 on, began a transformation of the telecommunications industry. Telephones for the first time became accessible to those other than the rich. By 2001, there were more subscribers to wireless phone lines than fixed-wire lines (16 million and rising vs. 12 million; San Diego Mercury News, 19 July 2000, p. 1C). The wireless services were supplied competitively by a half-dozen firms, while the fixed-wire services were provided by the incumbent monopolist, Telefonos de Mexico SA. As a result of the competition, consumers paid far less for wireless services than for fixed-wire services. The sums the wireless firms paid for their licensestotaling over $\$ 1$ billion - were no impediment to entry and did not keep the price of consumer services high.

\subsection{Electricity}

California's electricity deregulation was supposed to create "a market structure that provides competitive, low cost, and reliable electric service" (Los Angeles Times, 11 January 2001), according to the State Assembly bill that initiated it. But it didn't. The price of wholesale electricity rose to ten times what it had been. Governor Gray Davis labeled the move to markets "a colossal and dangerous failure" (Los Angeles Times, 14 January 2001).

Elementary supply and demand were at the heart of the crisis. Electricity supply was inadequate. Economic growth had brought increases in California's electricity usage, but few new generating plants had been built. Exacerbating the supply problem, at the time of deregulation unusually low rainfall and snowfall meant low water levels for hydro-generation and increased the need to use natural gas to generate electricity. At the same time there was a big increase in the price of natural gas.

In the old system, utilities operated as regulated monopolies: they could pass any cost increases on to their customers in higher rates and so had little incentive to hold their costs down. Deregulation meant wholesale electricity prices were set by competition rather than by a regulator. But the deregulation did not extend to retail prices, which continued to be held fixed, which meant that, when wholesale prices rose above retail prices, the utilities made losses. It also meant that demand-side pressures were lacking. Consumers had no price-based incentive to cut back at times when supply was short.

"We are so far into the realm of extraordinary gouging we are orders of magnitude off the chart," California Assembly Speaker Fred Keeley told the Federal Energy Regulatory Commission (FERC) in 2001 (San Jose Mercury News, 11 April 2001, p. 1A). Why did deregulation raise prices, rather than lowering them as it was intended to?

The special features of electricity make the performance of the market unusually sensitive to its design (Wilson 2002). Since electricity is costly to store, it must be produced as needed. Demand fluctuates. At peak demand 
times, all but a handful of generators are operating at their maximum capacity, and at such times those marginal producers can bid the price high.

The high prices were in part an ordinary market response to high demand, when it is the high-cost gas-fired plants, and not the low-cost hydro plants, that are the marginal suppliers. When demand hits a peak, therefore, marginal cost is high. Moreover, the price of natural gas rose dramatically in 2000 . The price of electricity was driven up by the cost of generation.

At times, however, prices rose far above the generation costs. "There is evidence that some generators may be withholding electricity," Governor Davis said, "to create artificial scarcity and drive up the price astronomically" (San Jose Mercury News, 11 April 2001, p. 1A). Such manipulation of the market would have been illegal. It may not have been unnecessary for the generators to illicitly collude, however. At peak demand, most generators cannot expand their output because they are already producing at their full capacity. For the few remaining generators, the bidding incentives can drive prices high even without coordinated bidding.

One company, Enron, used complex schemes with names like Fat Boy, Ricochet, and Death Star to manipulate prices by tens of millions of dollars. The state of California estimated the power suppliers overcharged it to the extent of $\$ 9$ billion during the crisis. The FERC agreed that overcharging had occurred, but disagreed about the amount: FERC ruled that the overcharging totaled $\$ 1.8$ billion (New York Times, 23 March 2001, p. A14; Financial Times, 13 December 2002, p. 8). ${ }^{3}$

\subsection{Pollution Control}

The U.S. government in 1990 introduced a new technique to reduce sulfur dioxide emissions, the main cause of acid rain. Replacing command and control, under which each polluting firm had been directly regulated by the Environmental Protection Agency (EPA), the act created a market in the rights to pollute. It defined emissions allowances, that is, licenses allowing the holder to emit one ton of sulfur dioxide in one year. The allowances were tradable: they could be bought, sold, or banked for future use.

To reduce its emissions of sulfur dioxide, a coal-burning electricity producer either installs scrubbers or switches to cleaner fuel. The costs of cleanup differ among plants, depending on location and the age and type of their equipment. Implementing command and control effectively would have required considerable knowledge on the part of the EPA of each individual plant.

3. For estimates of the gap between price and marginal cost, see Borenstein, Bushnell, and Wolak (2000) and Joskow and Kahn (2002). 
Tradable emissions allowances, by contrast, achieve pollution control flexibly. The total nationwide level of emissions is set by the government, which prints a total number of licenses equal to the target level of emissions. How much each plant cuts back is then set by the market. Those firms that find it relatively inexpensive to reduce their emissions sell some of their allowances and use the revenue to pay for their abatement activities (and have some profit left over). Those that find abatement relatively costly buy extra allowances. As a result, the target reduction in total emissions is achieved at the lowest possible cost to the industry.

The emissions-allowances program has been a success, according to various studies. The Environmental Defense Fund, an environmental group, said in its March 1995 newsletter that emissions trading "is cleaning up acid rain faster and far more cheaply than skeptics had predicted. The market system is unleashing inventiveness and showing that the cleanup need not put a heavy burden on the economy" (www.edf.org). The pollutants emitted fell below the ceiling the government had set. This was achieved at a cost to industry of billions of dollars less than the estimated cost of command and control. Air quality measurably improved. ${ }^{4}$

\subsection{Fisheries}

Fisheries are chronically overexploited. "The global marine fish catch is approaching its upper limit," according to an article in Science magazine (Botsford, Castilla, and Peterson 1997, 509). "Almost a half of the individual fish stocks are fully exploited, and another 22 percent are overexploited." The management of marine ecosystems "has failed to achieve a principal goal, sustainability."5

The overfishing results from the open-access nature of the fishery. In the absence of rules, the individual fishers have no incentive to conserve, because any fish they leave are taken by someone else. They cannot individually ensure the fish stocks are maintained.

Informal solutions to the open access problem work in certain circumstances. There are numerous examples of communities that have devised collective mechanisms to counter overfishing (Sethi and Somanathan 1996). Informal solutions, however, work only within tight-knit fishing communities. With large, anonymous groups of fishers that outsiders can enter, social sanctions hold little sway and so some kind of government intervention may be needed to prevent overfishing.

To regulate fisheries, governments have imposed controls, each of which has led to distortions. Regulatory controls on the number of boats have

4. For more on evaluating the program, see Ellerman et al. (2000), Bohi and Burtraw (1997), and EPA (1999). See also the EPA Web site, www.epa.gov/acidrain. For other environmental programs that use market incentives, see Daily and Ellison (2002) and Goldberg (2001).

5. For an excellent account of the fisheries crisis, see Grafton, Squires, and Kirkley (1996). 
brought bigger boats with extra equipment and crew. Restrictions on the length of the vessels have induced companies to build wider, heavier boats. Restrictions on the number of crew have resulted in investment in hightech fishing gear (adding electronic devices for locating fish increase a vessel's catch dramatically). Restrictions on equipment have meant the hiring of extra crew. Regulations specifying that fishing can take place only within a certain season induce firms to invest in high-capacity boats, so they can catch as much as possible in the time allowed; the investments sit idle for the rest of the year (Grafton, Squires, and Kirkley 1996; Grafton, Squires, and Fox 2000). And even with these regulations, the overfishing has continued.

Some governments have switched to a new, more market-based method of fish conservation. The regulators assign to each fishing vessel a quota, defining how much it is allowed to catch. Quotas directly address the basic issue - that overfishing is a consequence of the fact that no one owns the fish - by establishing property rights.

The New Zealand government introduced tradable quotas in the mid1980s. The aim was to reduce catches to sustainable levels. Quotas were allocated to individual fishers based on their prior investments in equipment. The quotas may be bought and sold. A new entrant or an incumbent wanting to expand needs to buy quotas. This means the quotas tend to end up with the most efficient producers.

When the New Zealand government wanted to reduce the total catch because of what it judged to be overfishing, it used a market process. It called for tenders from the fishers. A bid stated how much money the fisher would accept to reduce the allowed catch by a specified amount. The government accepted the lowest bids up to its target catch reduction, and paid each successful bidder the market-clearing price per ton of quota reduction (Sharp 1996, 442).

The tradable-quota system is an application of the idea of Ronald Coase (1960) of defining property rights so as to solve an externality. The system works effectively (Grafton, Squires, and Fox 2000; Straker, Kerr, and Hendy 2002). Fish stocks been conserved and fishers' profits have risen. Quota-holders have a stake in preserving the fishery in order to maintain the value of their quotas. In New Zealand, the fishers have formed associations to fund research aimed at conserving the stocks of scallops, snapper, and orange roughy. The creation of property rights has resulted, as Coase said it would, in the open-access externality's being internalized.

\subsection{Lessons on Markets as Policy Tools}

Some lessons can be drawn from these experiences in the use of markets by governments. Markets can be useful policy tools, primarily because they reveal information that otherwise might be unobtainable. But there are two 
crucial caveats, which seem obvious but are often overlooked. Markets can solve only certain kinds of problems, and they need to be implemented well.

\subsubsection{Markets Reveal Information}

The emissions-allowance market, like any other competitive market, generates information. ${ }^{6}$ It reveals how to allocate pollution reduction across firms in the way that brings the lowest total cost. It also reveals what the costs of reducing pollution actually are. Bureaucrats could, in principle, control pollution as cost effectively as the market by requiring extra reduction from those plants that have lower abatement costs. Realistically, however, they do not know where abatement costs are high and where they are low. It is the firms themselves that best understand how much it would cost them to cut their own pollution.

The EPA can know a firm's abatement costs only if the firm itself volunteers the information. The incentives under command and control worked against this. Managers, negotiating with the EPA, might exaggerate their firms' abatement costs in order to be assigned easier cleanup targets. The managers may even not have known how low their abatement costs could be driven, for under command and control they had little incentive to find out. Bureaucracy-run pollution controls are hindered by a lack of information. ${ }^{7}$ Under the market, by contrast, firms with low cleanup costs have a profit-based incentive to reveal this fact, by selling their allowances.

Before emissions trading began, the EPA estimated it would cost $\$ 750$ to clean up a ton of sulfur dioxide. The electric-power firms claimed it would cost them up to $\$ 1,500$. The average price at which the allowances actually traded over 1994-1999 was about $\$ 150 .{ }^{8}$ By selling an allowance for $\$ 150$, a firm was in effect saying that cutting its emissions would cost it no more than $\$ 150$ per ton. In other words, the market revealed cost of cleanup to be five to ten times less than had been previously suggested.

The spectrum auctions, similarly, revealed information. The multibillion-dollar prices reached seemed too high to some observers at the time,

6. For an overview of markets as information providers, see McMillan (2002).

7. It is theoretically possible to devise a centralized mechanism that induces firms to reveal their private information, along the lines of Baron and Myerson (1982). This would involve subsidizing the plants that reveal themselves to be low cost (and so are asked to do the most cleanup) and taxing the others. Such a mechanism is, however, difficult if not impossible to implement in practice.

8. The $\$ 1,500$ figure was stated in the 1990 Clean Air Act as the price of direct sales of allowances by the EPA, and the $\$ 750$ figure was cited by the EPA in 1990 as its best guess of the price at which allowances would trade (Bohi and Burtraw 1997, 8). The allowances prices ranged between $\$ 70$ and \$220 over 1994-1999 (see www.epa.gov/acidrain/ats/prices). The price of low-sulfur coal fell in a way that could not have been anticipated, and this explains part of the five- to tenfold difference between actual and predicted prices (Bohi and Burtraw; Ellerman et al. 2000). Much of it, though, is due to information generation. (Although pricing rules of the EPA auction tend to induce low prices, as I will discuss, this is not the explanation, for most of the transactions occur in the private market.) 
and even more so with the benefit of hindsight. In the frenzy of the bidding, the critics say, the telecommunications executives bid far above their estimates of value. If that were true, we should question their competence (as should their shareholders). But it isn't likely to be the correct interpretation. The auction prices revealed the industry's best current estimate of the value of the spectrum. Before there was competition, that knowledge stayed with the firms. The arrival of competition forced the insiders to reveal the value of the spectrum rights, and to pass much of that value on to the government.

The competitive process reveals information. After an auction, the seller knows which of the bidders values the item the most, and the price gives an estimate of value. There is a twist, however. The bidders are in part all trying to estimate the same thing, the future profitability of running mobile telecommunications services. This common-value feature means the bidders risk falling into the trap of the "winner's curse": that is, learning, too late, that the price has gone higher than the item is worth. If they are all knowledgable, then the best estimate is something like the average of their valuations. The winning bid, of course, is higher than the average bid. The winner is likely to be the bidder whose estimate is the most optimistic, probably overoptimistic.

In any auction, unwary bidders risk overestimating the value of winning. Bidders sometimes get caught up in the excitement of an auction and pay too much. But they need not be fooled. Experienced bidders avoid the winner's curse by bidding cautiously: They recognize they will win only if they have relatively high value estimates and bid accordingly lower. Alert winners need not be cursed. ${ }^{9}$ It is not especially difficult to avoid being subject to the winner's curse. All you have to do is understand precisely why there is a risk of bidding too high. The phrase "winner's curse" has in fact become common parlance in the telecommunications industry, suggesting the bidders did understand it.

The wisdom of hindsight is a different matter. Changes in the telecommunications industry subsequent to the auctions in some cases, such as the German and U.K. auctions, caused a rethinking of the value of the spectrum; but that is an ordinary business risk. In the optimistic late 1990s, the industry set a high value on spectrum, anticipating vast profits in the near future from mobile telecommunications. In the pessimistic years of 2000 2003, those profits failed to materialize, and the bid prices were seen to have overvalued the spectrum. But that is an ordinary business misjudgment, not something inherent in the auction process. Ironically, the telecommunications industry, long the recipient of government handouts, gave something back via the spectrum auctions to taxpayers.

9. On bidding to avoid the winner's curse, see Wilson (1969) and Milgrom and Weber (1982). On experiments with common-value auctions, see Garvin and Kagel (1994). 
In California's electricity deregulation, the market's information revelation was thwarted. Because wholesale prices sometimes far exceeded marginal production costs, they provided no useful information about the supply side of the market. And because retail prices were fixed, they were prevented from providing information about the demand side.

\subsubsection{Markets Must Be Well Designed}

The California electricity market tripped up on an elementary feature of market design. Prices were not allowed to do their job. Although the wholesale price at which the utilities bought power was market-set, the regulators fixed the retail price the utilities charged their customers. If the retail price had varied month by month to reflect wholesale prices, not only could the utility have avoided indebtedness, but consumers would have been motivated to conserve electricity. For business customers sophisticated meters allowing real-time pricing could have been installed. Businesses could shut down when prices were high, and run extra shifts when they were low. Peak-time power would thus be saved for other uses such as in homes. With the retail price fixed, the system had no way of responding to shortages.

Some critics say California's deregulation did not go far enough; it should have moved to fully free markets. Others say there should have been no deregulation, for markets for electricity cannot work. Both sides oversimplify. The deregulation fell short in retaining retail price controls and preventing prices from signaling scarcity; it went too far in eliminating restraints on overpricing by the generating companies. The problem was not too much or too little use of markets, but poor market design.

In its spectrum auctions the U.S. government adopted a novel form of auction, the simultaneous ascending auction, designed to address the specific features of the spectrum market. (For details of the market design, see McAfee and McMillan 1996 and Milgrom 2000.) The success of the spectrum auctions justified the choice of auction form.

With the tradable pollution licenses, by contrast, the market-design issue was not fully faced. The government put in place an auction for the allowances that was flawed - in a way that shows the importance of apparently innocuous features of the rules of the market game. (Cason and Plott 1996 pointed out this flaw in the EPA auction.) The market process was a double auction: potential sellers submitted price-quantity offers, and potential buyers submitted price-quantity bids. The rules for setting the prices unintentionally had the effect of giving not only buyers but also sellers incentives to bid low.

The poor auction design could have been a dampener on emissions trading. By luck, however, it turned out to have no ill effects. Bottom-up market creation compensated for flaws in the top-down market design. The emissions-allowances program was rescued by the emergence of a private 
market alongside the EPA auction. (In fact, the EPA envisaged its auction as a way of jump-starting the private market, and in this it succeeded.) Intermediaries took on the role of market makers, buying and selling allowances on behalf of clients and sometimes speculating on their own account. Although sellers may be deterred by the prospect of low prices from offering their allowances in the EPA auction, they have the alternative of the private market. The private market handles most of the transactions.

The secondary market in emissions allowances is easy to operate. One allowance is identical to another: it is simply the right to emit one ton of sulfur dioxide in a year. Because of the simplicity of what is being traded, it was not difficult to create a smoothly operating secondary market in emissions allowances. For this reason, in the case of emissions allowances, getting the market design wrong turned out to be inconsequential. With the emissions allowances, it was just a matter of leaving it to the market.

We cannot usually rely on secondary markets, however, to rescue a badly designed primary market. In the case of the spectrum auctions, a spontaneously developed secondary market could not be expected to operate efficiently (at least without a lengthy period of evolution). The very reasons why designing the spectrum auctions was nontrivial - the complementarities among the licenses - meant the secondary market would be plagued by high transaction costs and resulting inefficiencies. Because the secondary market could not be relied on, it was important to get the initial auction design right.

Emissions allowances are an exception that proves the rule. Generally, the design of a market must be watertight, especially when large sums of money are at stake. Any oversight in market design can have harmful repercussions, as bidders can be counted on to seek ways to outfox the mechanism. A newly instituted market achieves what it is supposed to only if it is well designed. The rules of the market matter. ${ }^{10}$

\subsubsection{Markets Do Not Supersede Regulation}

Emissions allowances do not take the government out of pollution control, but help it control pollution more efficiently. The government hands over to the market a part of its role: deciding how the emissions cutbacks are to be shared among the firms. But it retains its primary roles: assessing how much pollution in total is to be allowed, checking compliance, and fining any firms that break the rules.

In deregulated electricity markets also, government oversight continues to be needed. The transmission grid - the web of high-voltage lines that carry the power-is by its nature a monopoly, and so cannot be left to an unregulated market. Because of the physics of electricity, the operator of

10. For more on how the rules of market matter to its efficient operation, see McMillan (2002). 
the grid must constantly monitor it to ensure its reliability. The amount of power being pumped into the grid by the generators must always equal the amount being tapped by electricity users. The transmission system would be destabilized, bringing blackouts around the state, if there were a sudden uncompensated surge in the amount of electricity either being put in or drawn out. No matter how smoothly the retail and wholesale electricity markets operate, therefore, the grid needs continuing regulation.

Electricity-market regulation is needed also for competition-policy reasons. Because demand is insensitive to price and the consequences of a supply shortfall are severe, a few producers are, in periods if peak demand, in the position of being able to bid prices far above production costs. These high prices do not immediately call forth new sources of supply, since newgeneration facilities take years to come online. Unlike the case of the pollution allowances, private-sector intermediaries cannot step in to correct the official market's failings by starting their own marketplaces, for all the power must travel through the grid. Competition by itself cannot always be relied on to hold the price down close to generation costs. There continues to be a role for regulatory oversight of pricing.

With spectrum auctions, similarly, a role for the government remains. It continues to coordinate the usage of the spectrum by defining the purposes each wavelength band can be put to-broadcasting or various specific telecommunications applications. Some of this coordination role can in principle be passed on to the market: New Zealand is going the farthest in considering passing some of the spectrum management to the private sector. But the government still does the waveband equivalent of land-use zoning. The ultimate decision on how the publicly owned spectrum is to be used remains with the government. This is because there are externalities: users of adjacent wavebands might cause interference with each other. And reassigning spectrum as new technologies arise might require some central coordination.

With fisheries, also, creating and enforcing workable property rights requires ongoing government action. Quotas do not eliminate the need for regulatory supervision. The regulator must decide what level of total catch is sustainable. It must devise rules on who initially receives the quotas. Dividing up the rights to the catch is a source of contention among the fishers.

No system of monitoring, moreover, is infallible. New Zealand goes to great lengths to prevent out-of-quota fishing. It insists on full documentation, with paperwork recording each step of the fishes' journey from point of landing to final consumption or export. Fishers may not sell fish to anyone other than a licensed fish receiver. Catch reports, licensed-fish-receiver receipts, cold-storage records, and export invoices are all collated and checked for discrepancies. Overfishing and misreporting are criminal offenses. ${ }^{11}$

11. On monitoring, see Batkin (1996) and Squires, Kirkley, and Tisdell (1995). 
Property rights are not a free lunch. Transaction costs must be faced, as Coase (1960) stressed. Quota oversight is expensive. With a fishery, as with the other public-sector applications, resorting to markets does not remove the need for government action.

\subsection{Competition as a Tool of Redistribution}

In 1961 President John F. Kennedy issued an executive order requiring government contractors to "take affirmative action to ensure that applicants are employed and employees are treated during employment without regard to their race, creed, color, or national origin." Since then, affirmative action policies have waxed and waned. Of necessity, given the nature of the task, they have mostly taken the form of administered policies, including court-mandated correction of inequities in employment and university-admission rules favoring minority applicants. But market-based policies have also been used, particularly in government contracting and procurement.

Blacks and Hispanics have historically been underrepresented among owners of U.S. businesses. In part this was because of discrimination in the credit market. Studies of loan patterns have found that, controlling for factors like credit ratings and previous bankruptcies, blacks are less likely to receive bank credit than other entrepreneurs. Even in the absence of discrimination, underrepresentation can be self-perpetuating. In industries like construction, when an upcoming job is announced, some preselected firms are invited to bid for it, based on their having done good work in the past. For minority-owned firms this was a catch-22. They could not bid for a contract, because they were not put on the list of invitees, because they had not had a contract.

Affirmative action in government contracting was intended to increase the disproportionately small share of government contracts going to minority-owned firms. It has been a success, as measured by a markedly increased share of contracts held by minority firms and an increase in black employment. The evidence on the program's costs is sketchy, but what there is suggests that they have been low (despite some fraud, with phony minority-owned firms being created as a front for white-owned firms in order to receive the preferences). The price paid relative to the government's prior cost estimate has been on average little different for minority firms benefiting from preferences than for others. In New Jersey, the introduction of preferences sharply increased the share of contracts going to minority firms, but their cessation a few years later brought no reduction in the share, suggesting that the minority firms had been given a jump start by the program and then had been able to stand on their own. ${ }^{12}$

12. The foregoing draws on Holzer and Neumark (2000). 
The U.S. government, as well as state and local governments, used two kinds of affirmative-action policies in contracting. One was to guarantee that certain contracts went to minority-owned firms. A contract was offered to a single minority firm without competitive bidding, or the contract was put up for bidding on a set-aside basis, meaning that only minority-owned firms could bid for it. An alternative policy, that of price preferences, consisted of designing the market's rules so as to achieve the policy goal. Contracts were put up for bid in the normal way, but with the difference that minority-owned firms received a price break. Before the government compared the bids, it subtracted a specified amount from the minority-owned firms' bids, usually 10 percent, meaning a minority firm could win if its bid was higher, by no more than 10 percent, than a nonminority firm's bid.

Mayor David N. Dinkins introduced a 10 percent price preference for firms owned by minorities or women into New York City's municipal contracting in 1993. One year later, according to a report issued by the Dinkins administration, minority- and women-owned companies' share of the contracts had risen sharply, from 9.0 percent to 17.5 percent. The cost of the program through not selecting the lowest bids, the report said, was $\$ 2.7$ million, or 1 percent of the total contracting budget. The city of Los Angeles implemented a similar price-preference program.

Government preferences were controversial. The New York program was abolished by Mayor Rudolph W. Giuliani, not only on the grounds of cost but also from a philosophical objection to affirmative action. California voters voted in a 1996 ballot initiative to end affirmative action programs. Los Angeles then replaced its affirmative action program with a 5 percent price preference for any small firm. Since many of the small businesses are owned by minorities and women, however, the small-business price break meant that the Los Angeles contracts were still steered toward them (the share of city spending going to minority firms rose from 12 percent in 1996 to 15 percent in 2000; New York Times, 2 February 1994, p. B2; San Jose Mercury News, 4 December 2000, p. 1A).

Setting aside a contract for one or a few bidders necessarily increases the price paid by the government, since, with bidding competition eliminated or reduced, there is no reliable way of identifying which firm would have the lowest cost of doing the job. A price preference, by contrast, can be a free-lunch policy. It not only addresses the public-policy goal of increasing the number of contracts going to the minority firms, but it also could actually sometimes lower the average price the government pays its contractors. ${ }^{13}$ With price preferences, a minority firm would win if its bid was no more than 10 percent higher than the lowest bid from a nonminority firm. The minority firms typically have a higher cost of carrying out the con- 
tracted work than the nonminority firms (because of lack of access to capital and lack of experience). They would therefore impose little competitive pressure on the nonminority firms, which could, if there were little competition among themselves, get away with bidding relatively high. A price preference for the minority firms stimulates the bidding competition, forcing the nonminority firms to bid lower. Depending on the level of the price preference, its price-lowering effect (from the lower bids from the nonminority firms) could sometimes outweigh its price-raising effect (from the chance that a minority firm wins and must be paid a relatively high price). The price preferences, therefore, should not much increase the government's overall contracting bill; they are more cost effective than the alternative of earmarking some contracts for minority firms. Price preferences can help level an unlevel playing field.

This logic came to play in the designing of the spectrum auctions. Congress required the Federal Communications Commission (FCC) to "ensure that small businesses, rural telephone companies, and businesses owned by members of minority groups and women are given the opportunity to participate in the provision of spectrum-based services" (U.S. Congress 1993). The first two FCC auctions included price preferences, of as much as 40 percent. FCC chairman Reed E. Hundt described the preferences as offering "the single most important economic opportunity made available to women and minorities in our country's history" (McAfee and McMillan 1996, p. 167). They were controversial, however. "We want a guarantee of spectrum competition," wrote William Safire in the New York Times. "The criterion to determine competition must be scrupulously economic, not jiggered by the Government to introduce sexual or racial or ethnic or ideological favoritism" (New York Times, 16 March 1995). Despite revealing a misunderstanding of the effects of price preferences - as just argued, they could actually make the bidding more competitive - such views became dominant. When the mood in Washington turned against affirmative action, the FCC scrapped the preferences from subsequent auctions. Nevertheless, where they were used they succeeded in their policy aim of helping some minority-owned firms enter the mobile telecommunications industry.

Market mechanisms, then, can in some circumstances be called upon to help with redistribution toward the disadvantaged - and can achieve it more cost effectively than administrative methods.

\subsection{Conclusion}

In picking winners, governments have a poor track record. Picking winners is exactly what the government is called upon to do when it makes allocation decisions such as which firm gets the right to use a publicly owned resource. A market-based allocation leaves the government to do what only it can do, while turning over to the market the job of picking winners. 
Competitive markets, if well designed, can reveal the information that is needed for allocating the resources efficiently. Markets do not replace the government's regulatory role, but in the right circumstances they can be an effective instrument of regulation.

\section{References}

Baron, David P., and Roger B. Myerson. 1982. Regulating a monopolist with unknown costs. Econometrica 50:911-930.

Batkin, Kirsten M. 1996. New Zealand's quota management system: A solution to the United States' Federal Fisheries Management crisis? Natural Resources Journal 36 (4): 855-880.

Bohi, Douglas R., and Dallas Burtraw. 1997. $\mathrm{SO}_{2}$ allowance trading: How experience and expectations measure up. Discussion Paper no. 97-24. Washington, D.C.: Resources for the Future, February.

Borenstein, Severin, James Bushnell, and Frank Wolak. 2000. Diagnosing market power in California's restructured wholesale electricity market. NBER Working Paper no. 7868. Cambridge, Mass.: National Bureau of Economic Research, September.

Botsford, Louis W., Juan Carlos Castilla, and Charles H. Peterson. 1997. The management of fisheries and marine ecosystems. Science 277 (July): 509-515.

Cason, Timothy N., and Charles R. Plott. 1996. EPA's new emissions trading mechanism: A laboratory evaluation. Journal of Environmental Economics and Management 30:133-160.

Coase, R. H. 1960. The problem of social cost. Journal of Law and Economics 3:144.

Daily, Gretchen C., and Katherine Ellison. 2002. The new economy of nature. New York: Island Press.

Ellerman, A. Denny, Paul L. Joskow, Richard Schmalensee, Juan-Pablo Montero, and Elizabeth M. Bailey. 2000. Markets for clean air. New York: Cambridge University Press.

Environmental Protection Agency (EPA). 1999. Progress report on the EPA acid rain program. Washington, D.C.: EPA. Available at www.epa.gov/acidrain.

Garvin, Susan, and John H. Kagel. 1994. Learning in common-value auctions. Journal of Economic Behavior and Organization 25 (December): 351-370.

Goldberg, Beth. 2001. Auctioning $\mathrm{CO}_{2}$ permits: A business-friendly climate policy. In Redefining Progress [booklet]. Oakland, Calif.

Grafton, R. Quentin, Dale Squires, and Kevin J. Fox. 2000. Private property and economic efficiency: A study of a common-pool resource. Journal of Law and Economics 43:679-714.

Grafton, R. Quentin, Dale Squires, and James E. Kirkley. 1996. Private property rights and crises in world fisheries. Contemporary Economic Policy 14:89-99.

Holzer, Harry, and David Neumark. 2000. Assessing affirmative action. Journal of Economic Literature 38:483-568.

Joskow, Paul, and Edward Kahn. 2002. A quantitative analysis of pricing behavior in California's wholesale electricity market during summer 2000. Energy Journal 23 (4): 1-35.

Klemperer, Paul. 2001. What really matters in auction design. Journal of Economic Perspectives 16 (1): 169-189. 
McAfee, R. Preston, and John McMillan. 1987. Auctions and bidding. Journal of Economic Literature 25 (2): 699-738.

1996. Analyzing the airwaves auction. Journal of Economic Perspectives 10:159-176.

McMillan, John. 2002. Reinventing the bazaar: A natural history of markets. New York: Norton.

Milgrom, Paul. 2000. Putting auction theory to work: The simultaneous ascending auction. Journal of Political Economy 108:245-272.

Milgrom, Paul R., and Robert J. Weber. 1982. A theory of auctions and competitive bidding. Econometrica 50:1089-1122.

Sethi, Rajiv, and E. Somanathan. 1996. The evolution of social norms in common property resource use. American Economic Review 86:766-788.

Sharp, Basil M. H. 1996. Natural resource management. In A study of economic reform: The case of New Zealand, ed. B. Silverstone, A. Bollard, and R. Lattimore, 425-429. Amsterdam: North-Holland.

Squires, Dale, James Kirkley, and Clement A. Tisdell. 1995. Individual transferable quotas as a fisheries management tool. Reviews in Fisheries Science 3:141-169.

Straker, Gina, Suzi Kerr, and Joanna Hendy. 2002. A regulatory history of New Zealand's quota management system [booklet]. Wellington, N.Z.: Motu Economic and Policy Research, August. Available at www.motu.org.nz/nz_fish.htm.

U.S. Congress. 1993. Omnibus Budget Reconciliation Act of 1993 Conference Report [HR 2264], Title VI, "Communications Licensing and Spectrum Allocation Improvement." Report 103-213, August.

U.S. Shadow Financial Regulatory Committee. Reforming bank capital regulation. Washington, D.C.: AEI Press.

Wilson, Robert B. 1969. Competitive bidding with disparate information. Management Science 15:446-448.

2002. Architecture of power markets. Econometrica 70:1299-340.

\section{Comment Kyoji Fukao}

As I am not an expert on industrial organization, my comments will be of a general nature.

This paper reviews four examples of public-sector uses of markets and derives several important lessons; for example, markets reveal information and markets must be well designed. I found the paper quite informative, because the author provides very clear explanations of complicated issues such as electromagnetic-spectrum auctions and the retail market for electricity. Moreover, I basically agree with the author's argument on the lessons to be learned. I have four comments.

My first comment is on theory. The author argues that the desirability of the introduction of a market and optimal market design depend crucially on the characteristics of the goods that will be traded. However, these issues are not addressed systematically. If the author provided us with a gen- 
eral theory on the use of the market, this would be very helpful. Let me give an example. Important characteristics of goods can be classified into several factors. First, difficulties in establishing and protecting property rights are an important factor. In the case of fisheries and pollution, monitoring the property rights is expensive. Second, difficulties in storage and elasticity of intertemporal substitution are another important factor. If it is difficult to store goods, as in the case of electricity, we will have quite volatile spot prices and the introduction of forward markets will be an important issue. Third, the risk of market power abuses is another important factor. If the author drew a figure, or table, in which each axis denotes one of these characteristics, and located each good in this figure, the theoretical analysis of the paper would become clearer.

My second comment is on the relationship between the use of markets and privatization. The author does not show us explicitly how his argument is related to the privatization issue. If the author elaborated on this issue, the reader would be able to better understand the close relationship between this and other papers presented at this seminar. Let me give an example. In the case of industries in which networks for transmission and distribution are important, such as electricity, telecommunications, and railroads, it is sometimes desirable to continue regulating the "wires" business, and to privatize the industry through vertical separation. In such cases, the design of the wholesale market is a very important issue.

My third comment regards data on market prices. If some data on market prices were provided in the paper, the author's argument would become more persuasive. For example, I would like to see some figures for the wholesale price of electricity. International or interregional comparisons of price levels also would be informative. If the author could compare the average price level for the electromagnetic spectrum among countries and analyze what market characteristics affect the price level, this would enhance the study.

My last comment regards international aspects. I think that whether foreigners are permitted to participate in a new market or not, and whether goods are internationally tradable or not, are pertinent topics. I would like to ask the author to consider these issues in his future work.

\section{Comment Tsuruhiko Nambu}

This paper is quite insightful; it gives us an opportunity to rethink the tide of deregulation or join a chorus for market mechanisms. As far as there exist public policy goals, a third party must remain to solve this task. With-

Tsuruhiko Nambu is professor of economics at Gakushuin University. 
out this entity, one variable is missing for solving the overall social system. This is common sense, but its meaning is clearly verified by considering four episodes: pollution control, electricity, spectrum allocation, and fishery management. In three cases of the four, market mechanisms worked to a remarkable extent to help government realize public goals. But in one case, electricity, we witnessed a total failure in California.

In the first three cases, the task of government is to assign property rights: to give proper incentives to realize public objectives. In the last case, government intervened in the old market paradigm, namely vertical integration, to create an unbundled system. I think the cases of pollution and fisheries are readily understandable because they are based upon approving vested interests without asking for distributional fairness at the start. If the eventual result is acceptable from the viewpoint of public policy, then the initial distribution of rights does not matter: this is a pragmatic approach.

Less convincing is the case of spectrum auctions. It is true that auctions reveal the value of spectra, but I wonder whether they offer an efficient solution. Let us look at the U.S. telecommunications industry, where entry into local markets used to be forbidden by the consent decree. Longdistance carriers wished to enter the local market. They employed a strategy to make use of cellular telephony to beat regional Bell operating companies (RBOCs). Because of the constraints on long-distance carriers, their willingness to pay for an electromagnetic spectrum might be greater than without constraints. It may have pushed up prices more than necessary. The move of RBOCs to defend their markets may have accelerated this price increase. Summing up, I wish to say that institutional bias surrounding the telecommunications industry would harm the auction results. Looking at the reality that AT\&T is said to divest its cellular division may help us understand the situation.

I fully agree with the discussion on electricity failure in California. One comment may be in order when we remember the bad relationship between the Public Utility Commission and electricity companies in California. In transition from the old system to new, some constructive talks were necessary, especially when knowledge was owned one-sidedly by the incumbent firms. If regulated firms do not have any incentive to collaborate with regulators who impose transition costs on them, they will not teach their secrets, later possibly inducing a breakdown of the system. In my guess, this was the case of mustrun electric power-generating plants sold off by the electric power utilities. Many experts say that these should not have been allowed to be sold off so as to maintain voltage control. But California utilities, it seems, did not pay attention to this problem. There may have been discussion over these matters if there had existed smoother communication between regulated firms and the regulator. This kind of relationship is dependent on history, and I think we need to be sensible of this path dependence. 
